\title{
DYNAMIC MODALS - ENGLISH AND SERBIAN CONTRASTED
}

\author{
UDC 811.111'36:811.163.41'36
}

\author{
Aleksandra Radovanović \\ University of Kragujevac, Faculty of Hotel Management and Tourism, Vrnjačka Banja, \\ Serbia
}

\begin{abstract}
The current study attempts to investigate the semantic domain of dynamic modality in English and Serbian by focusing on the dynamic modals in English and their translation equivalents in Serbian. It tends to fill the existing research gap regarding a comprehensive contrastive analysis tackling all dynamic modality subtypes in the investigated languages. Cross-linguistically, modality is expressed by different grammatical categories with a tendency for typologically related languages to convey modal meanings by similar devices. We expect the analysis to show that both English and Serbian have grammatical devices to express dynamic modal meanings and that dynamic modality is expressed in similar ways in the two languages. Two complementary objectives underlie the analysis: to identify and provide an account of the devices used to express dynamic modality in English and Serbian and to compare and contrast the two languages. The unilateral contrastive analysis, guided by the principles set in Đorđević (1994), used a semantically based tertium comparationis, i.e. the principle of translation equivalence seen in terms of semantic equivalence. The analysis was carried out on the corpus compiled for these purposes comprising the excerpted examples from two novels by Kazuo Ishiguro (Ishiguro 2005, 2016) and their published Serbian translations (Išiguro 2003; Ишигуро 2009).
\end{abstract}

Key words: dynamic modality, English, Serbian, possibility, necessity, volition.

\section{INTRODUCTION}

As an inherent property of human cognition and a complex multilayered category on the interface of several linguistic subfields, modality keeps arousing researchers' interests. Yet, as it was often commented on (e.g. Nuyts 2006; Trbojević-Milošević 2004), despite a large and growing body of research investigating modality, to date there has been little agreement on its precise and concise definition. Largely inspired by Palmer's seminal monographs $(1979,1986,2001)$, researchers typically approach it by clearing up the confusion over mood and modality and offer definitions that rest on setting distinctions

Submitted July $21^{\text {st }} 2017$, accepted for publication November $13^{\text {th }}, 2017$

Corresponding author: Aleksandra Radovanović

Faculty of Hotel Management and Tourism,Vrnjačka Banja, Serbia

E-mail: aleksandra.radovanovic@kg.ac.rs 
between semantic notions and concepts underlying the semantic core of modality. Relying on the tradition adopted from modal logic, linguistics see modality as a domain based on the binary opposition possibility/necessity, but other oppositions were put forward as well. ${ }^{1}$

The basic binary division of modal meanings was equally stressed, again, with different labels. As it, in fact, extends far beyond modality, or even language, and relies on the wider distinction between the two language uses, to inform and to act (Palmer 1986:20), it is best addressed in terms epistemic and deontic. Epistemic modality is concerned with belief, knowledge, truth, etc. in relation to the proposition, whereas deontic deals with actions by others and by the speaker himself (Palmer 1986:96). Together with dynamic modality, they are the cornerstones of the widely accepted Palmer's tripartite classification (e.g. Huddleston \& Pullum 2002; Novakov 2012; Пртљага 2008; Salkie 2009). The study adheres to it and generally follows Palmer's line of reasoning (1979, 1986, 2001). Hence, modality is viewed as a notional category defined on semantic grounds synthesised with formal criteria and comprising dynamic modality (DynMod). ${ }^{2}$ Regardless of the non-uniformity concerning the semantic scope and contentious issues concerning the status of DynMod, based on various semantic and syntactic grounds (e.g. Gisborne 2007; Salkie 2009), ${ }^{3}$ this study focuses on this semantic domain in English and Serbian.

Dynamic modality, the term introduced by von Wright in modal logic (Palmer 1986:12), is traditionally characterised as an ascription of a capacity to the subject-participant of the clause (Nuyts 2006:3), i.e. as a modality that refers to properties and dispositions of persons etc. referred to in a clause (Huddleston \& Pullum 2002:178). Adopting the proposals set forth by Palmer $(1979,2001)$, this paper regards it as the modality of events that are not deontically conditioned. Unlike deontic modality, the conditioning factors are internal to the relevant individual (Palmer 2001:9). Further, DynMod also suggests that there are circumstances in the real world that make the actualization of the event possible/necessary (Palmer 1979:39). Thus, to provide a systematic analysis, a two dimensional semantics matrix is taken into account with necessity and possibility being in a vertical plane and DynMod sub types (neutral and subject oriented) in a horizontal one (Palmer 1979).

Due to practical constraints, the analysis is limited to English dynamic ${ }^{4}$ modals comprising central modal auxiliaries and semi-modals. Unlike English modals, whose features received significant attention as they frequently provided the basis for investigating modality in English and cross-linguistically, Serbian modals do not form a closed distinct set and thus were not treated as a significant category until recently. ${ }^{5}$ Based on their specific semantic and morpho-syntactic features, they were classified in various ways, yet this study relies on the classification provided by Hansen (2007). In line with contemporary trends in linguistics, the past decades have seen a surge of interest in Serbian modals. Researchers mostly dealt with their morpho-syntactic behaviour and semantic characteristics (Hansen 2007), and approached

\footnotetext{
${ }^{1}$ Besides subjective/objective, there is a range of terminological solutions denoting basically the same opposition (non)factivity, (non)factuality, (ir)realis, (un)actuality), (non)assertiveness (Trbojević-Milošević 2004).

${ }^{2}$ As regards the classification, Palmer (1986) is an exception.

${ }^{3}$ The proposed arguments can be briefly summarised as follows: dynamic modality is part of the propositional content of the clause, dynamic modals do not express the attitude or opinion of the speaker, neither the speaker influences the situation, they lack subjectivity and syntactically differ from other modals (they can be used in the past tense with reference to past time and with negative forms only modality is negated).

${ }^{4}$ The term dynamic is applied not only to the modality type but also to the modals when they express this type of meaning.

${ }^{5}$ For a comprehensive review of modals and modality treatments and classifications in English and Serbian, see Јанић - Стаменковић (2016), Novakov (2007), Trbojević-Milošević (2004).
} 
them from a theoretical (Кликовац 2011) or contrastive perspective (Kalogjera 1970; Радовановић - Војводић 2005; Радовановић 2012, Trbojević-Milošević 2004). Although the most prominent dynamic modals in English and Serbian came into the focus of contrastive studies (Јанић - Стаменковић 2016; Novakov 2012; Пртљага 2008), a comprehensive study tackling the DynMod subtypes in the two languages lacks.

The analysis was built on the following assumptions. Modality is a semantic category that, as evidenced and well documented by typological studies, exists in many, if not all, languages and is expressed by different grammatical categories. Cross-linguistically, there is a tendency for typologically related languages to express modal meanings by similar devices, thus it is expected that both English and Serbian should have grammatical devices to express DynMod and that it is expressed in similar ways in the two languages.

Cross-linguistically, the semantic category of modality is expressed by different grammatical categories, but there is a tendency for typologically related languages to convey modal meanings by similar devices. Thus, we expect that the analysis will show that both English and Serbian have grammatical devices to express dynamic modal meanings and that DynMod is expressed in similar ways in the two languages.

Two complementary objectives underlie the study: 1) to identify and provide an account of the devices used to express DynMod in English and Serbian and 2) to compare and contrast the two languages. Accordingly, the methodological framework comprises a qualitative and contrastive analysis. The unilateral contrastive analysis, guided by the principles set in Đorđević (1994), used a semantically based tertium comparationis, i.e. the principle of translation equivalence seen in terms of semantic equivalence. The analysis was carried out on the corpus comprising the excerpted examples from two novels by Kazuo Ishiguro (Ishiguro 2005, 2016) and their published Serbian translations (Išiguro 2003; Ишигуро 2009). The contrastive sentential corpus containing 512 relevant examples in both English and Serbian was compiled for these purposes. The English novels were manually searched for the modals conveying DynMod defined as previously described after which their translations were excerpted form the novels in Serbian. The instances of the English dynamic modals clearly expressing other modality types were disregarded. The established similarities, contrasts and differences provided in the conclusion were formulated based on semantic equivalency of the identified translation equivalents (TEs).

\section{DYNAMIC POSSIBILITY}

Dynamic can, could and be able to ${ }^{6}$ used for neutral present or timeless possibility typically indicate that the event is possible and can be glossed as it is possible for. Could stands for tentative and hypothetical possibility (3) (Leech \& Svartvik 2002:113), so, the weaker possibility meaning is sensed. When can/could (harmoniously) combine with the adverb possibly, the extent of possibility is lowered, almost minimal.

(1) Because you can see it best from here. (Ishiguro 2005:229)

(2) Зато што га најбоље можете видети одавде. (Ишигуро 2009:231)

(3) What could we do to her?" (Ishiguro 2005:33)

(4) Шта бисмо јој могли учинити? (Ишигуро 2009:36)

\footnotetext{
${ }^{6}$ Be able to covers most uses of can described below exclusive of those with existential modality meaning and private verbs.
} 
(5) Kath, can I just have a quick word? (Ishiguro 2005:85)

(6) Кет, могу ли ти накратко нешто рећи (Ишигуро 2009:88)

As can in (1) focuses on the current and future state of circumstances, the description in terms of circumstantial possibility is more appropriate (Hoye 1997:86). Next, for an adequate interpretation of (5), an expansion into pragmatics is needed. Being more than a mere question on possibility, it is to be interpreted as a request. Thus, Collins (2009:96) views this as the dynamic implicature use of can as it involves potentiality for an action that is the basis for an implied directive speech act. The illocutionary force of other utterances with dynamic implication from our corpus includes: offer, invitation, suggestion, and can is also found in conversational phrases to increase the level of politeness. ${ }^{7}$

Further, as illustrated by (3), it is hard to separate neutral from subject oriented possibility (ability) as they overlap significantly and are united through the concept of potentiality (Collins 2009). Hence, ability is considered a special case of possibility meaning (Quirk et al. 1985:222) as it implies possibility: if someone has the ability to do $X$, then $X$ in a sense is possible (Leech 1987:74). ${ }^{8}$ Ability refers to the characteristics of the subject seen as the circumstances making the actualization of the event possible and encompasses both physical (7) and psychological ability, acquired skills/knowledge (9) or those someone was born with (11), i.e. the meanings more or less equivalent to know how to or be capable of.

(7) I can go much faster! (Ishiguro 2016:21)

(8) Mogu ja mnogo brže! (Išiguro 2003:50)

(9) Can I do bathrooms? (Ishiguro 2016:32)

(10) Umem li da uredim kupatilo? (Išiguro 2003:73)

(11) They say Bill can cook better than his wife. (Quirk et al. 1985:222) ${ }^{9}$

(12) Кажу да Бил кува боље од своје жене.

Whereas in only several examples can seems to indicate ability clearly and in few be able to refers to present ability, far more frequently are be able to and could used for past ability (13). This might be related to actuality entailment. Unlike can that might indicate future actuality, could, indicating what would be or would have been experientially possible, is not used if there is the implication of actuality (Palmer 1979:80). Thus, be able to is preferable for strong actuality implications (Palmer 1986:95) and can be captured by managed to (13). Yet, this distinction does not hold in (15) as could indicates general possibility over a period of time, not a possibility that resulted in one actualized event.

(13) We were able to do that much for you at least. (Ishiguro 2005:261)

(14) Били смо у стању да макар толико учинимо за вас. (Ишигуро 2009:263)

(15) You could talk about things there you wouldn't dream of talking about any other place... (Ishiguro 2005:15)

(16) Ту се причало о стварима о којима не бисте ни сањали да говорите на било којем другом месту... (Ишигуро 2009:18)

\footnotetext{
${ }^{7}$ For instance: How can I put it, sir? (Išiguro 2016: 2).

${ }^{8}$ Based on the fuzzy and non-categorical distinctions between these meanings, Coates and Leech (1980) claimed that can is the only monosemantic modal with various sub senses unified and distributed along the gradient with no absolute cut-off points.

${ }^{9}$ As relevant, this example is supplied from the literature.
} 
The subject oriented can with inanimate subjects indicates they have the necessary qualities, or the power, to cause the event to occur (Palmer 1979:73) (17). As can in this use roughly has the meaning of implicit existential quantifiers (some or sometimes), it is semantically close to can referring to the characteristic behaviour of animates (19).

(17) ... things can get a little lonely at times. (Ishiguro 2016:101)

(18) ... čovek može ponekad da bude baš usamljen (Išiguro 2003:222)

(19) He can be fussy. (Ishiguro 2005:155)

(20) Он зна да буде ситничав. (Ишигуро 2009:203)

Furthermore, can in (17) and (19) yields an epistemic reading with the gloss It can happen that ${ }^{10}$; thus these also exemplify existential modality that represents borderline cases between the dynamic and epistemic interpretation (Palmer 1979:152-153). Yet, again, the meaning boils down to possibility, theoretical possibility (the possibility of the idea) (Leech 1987).

Quite distinct is the use of can/could with private verbs. (21) states that the speaker has a certain sense, not that he possesses ability for such sensory perception (Palmer 1986:75). Although possibility/potentiality meaning can be retained (1) ${ }^{11}$, can in this idiomatic use provides the ordinary stative meaning to perception verbs, i.e denotes a state rather than event (Gisborne 2007:54; Leech 1987:74).

(1) Because you can see it best from here. (Ishiguro 2005:229)

(21) Incidentally, Mr Ryder, I can see you're about to ask, I will tell you, I will assure you. (Ishiguro 2016:181)

(22) Uzgred, g. Rajder, vidim da želite da mi postavite pitanje, reći ću vam, uveriću vas. (Išiguro 2003: 390)

(23) The boy! He can hear. (Ishiguro 2016:112)

(24) Dečak! Čuće! (Išiguro 2003:246)

Far less frequent are the instances of may and dare. May is a dynamic modal when used as a formal substitute for neutral can (Quirk et al. 1985:223), as its purely stylistic variant (Hoye 1997:99). In (25), the modal representing factual/epistemic possibility (Leech 1987: 82) is used for theoretical possibility. Dynamic modal dare ${ }^{12}$, roughly meaning have the courage to, indicates that the subject does not have/has the necessary qualities to perform the action, i.e. disposition (27). It also occurs in a formulaic expression in the affirmative (I dare say) and in idiomatic functions expressing a threatening rebuke in the interrogative (Quirk et al. 1985:139).

(25) But now you've arrived, this may change things. (Ishiguro 2016:229)

(26) Ali sada, kada ste stigli, to bi moglo da promeni stvari. (Išiguro 2003:491)

(27) ...I daren't be late. (Ishiguro 2016:28)

(28) ...ne usuđujem se da zakasnim. (Išiguro 2003:66)

(29) ...не смем да закасним.

\footnotetext{
${ }^{10}$ Here, the semantics of can is similar to that in a widely quoted example Lions can be dangerous (e.g. Palmer 1979: 152).

${ }^{11}$ The example is repeated for practical purposes.

${ }^{12}$ Dare has a unique status as it expresses only this one type of modality.
} 
In Serbian, a fully-fledged modal auxiliary ${ }^{13}$ moć $i$ is the central exponent of DynMod covering the meanings of can, could and be able to: neutral and subject oriented possibility, including pure physical ability or capacity, and existential meanings. As a TE of could, it mostly appears in a conditional tense, which heightens the possibility meaning as most modal meanings of the conditional mood are related to possibility (Пипер - Клајн 2013:406). The subject oriented possibility meanings are also rendered by verbs umeti and znati and modal adjectives biti $u$ stanju/kadar. Although both verbs are used for habitual/sporadic activities, they do not correspond completely to can. The subject's internal characteristics are also signalled by the (in)ability modal smeti (Радовановић - Војводић 2005) which is, along with a lexical verb usuditi se, a TE of dare. As dare, dynamic smeti indicates the inherent capacity.

TEs reveal a shift of DynMod meanings. The semantic value of can is not maintained in some of its abilitative uses when it is replaceable by the Serbian indicative present (11). Also, when used with private verbs, the factual declarative statements occur as TEs of much less categorical forms. The same difference is noted with see used for mental perception (I can see) (Quirk et al. 1985:623) (27). It is best described as an idiomatic use (Kalogjera 1970:75; Hoye 1997:92) translated with appropriate idiomatic expressions shvatam, sagledavam, jasno mi je, razumem.

Further, the modal meaning can be changed, infrequently though. Unlike (23), (24) yields an epistemic reading as the indicative future has an inferential, predictive meaning proved by back-translation He will hear and the plausible interpretation Judging from our tone of voice and the boy's location, it is highly probable that he hears.

\section{DYNAMIC NECESSITY}

A predominantly deontic modal must has dynamic necessity as a minor meaning (Collins 2009). In this use, it lacks performativity and does not imply that the speaker is a kind of authority imposing the obligation. As people generally do not lay obligations on themselves, must with $1^{\text {st }}$ person subjects conveys dynamic necessity glossed as It is necessary for (30). The semantic contrast between must and have to is associated with the source of necessity: the latter implies obligation by external forces (Palmer 1979:92; Quirk et al. 1985:226). Thus, in (34) have to indicates objective necessity to perform the action and it could have been used in (30) for politeness, as a means for the speaker to present his intention as a necessity imposed by external factors. Nonetheless, as (32) illustrates, have to ${ }^{14}$ also expresses the internal necessity of the subject, which can be quite evident.

(30) I'm sorry, students, but I must leave you now. (Ishiguro 2005:266)

(31) Жао ми је, ђаци, али сада вас морам напустити. (Ишигуро 2009:268)

(32) Do you ever get so you just really have to do it? (Ishiguro 2005:128)

\footnotetext{
${ }^{13}$ According to Hansen (2007), fully-fledged modals are polyfunctional expressions of modality that syntactically behave like auxiliaries. It should be noted that epistemic uses can be distinguished on syntactic criteria as modals occur in impersonal, agentless form in this use. Unlike the English modals, the Serbian modals are used in tensed forms.

${ }^{14}$ As the difference between have to and have got to is associated with style, not the meaning, apart from the difference related to the actuality implication entailed only by the former (Palmer 1979:92), the discussion applies to the latter as well.
} 
(33) Да ли ти се икада дешава да дођеш у такво стање да то мораш да урадиш? (Ишигуро 2009:132)

(34) Then you have to draw in all these different details for them. You have to think about how they'd protect themselves, how they'd reach things. (Ishiguro 2005:178)

(35) Потом треба да уцрташ све те разне детаље на њима. Мораш да размишљаш како ће заштити себе, како ће дохватити ствари. (Ишигуро 2009:182)

Further, a high level of semantic overlap is noted as both occur in assertive statements viewed as circumstantial necessity and interpreted the circumstances compel. In (36), the necessity clearly emerges from the given circumstantial factors. Again, the possible semantic distinction between the two relates to the actuality implication the semi-modals tend to entail. Yet, it does not hold in negative contexts when they differ completely. The dynamic meaning is maintained only with the negative of have to as the modality is negated. ${ }^{15}$ The negative form of need also functions as the semantic negative of must expressing the absence of necessity/need. Need, whose main meaning is dynamic necessity (Collins 2009:57), expresses an internally imposed need (38) or that imposed by external circumstances (40).

(36) Your life must now run the course that's been set for it. (Ishiguro 2005:266)

(37) Ваш живот сада мора тећи предвиђеним током. (Ишигуро 2009:267)

(38) But why need I say this? (Ishiguro 2016:254)

(39) Ali zašto ovo govorim? (Išiguro 2003:544)

(40) ...need I spell it out to you? I see I must. (Ishiguro 2016:74)

(41) ...da li je potrebno da vam je detaljno izložim? Vidim da moram. (Išiguro 2003:163)

In terms of modal strength, must and have to are considered strong modals. Thus, they differ from semantically very close, often interchangeable, modals should and ought to that express the intermediate strength modality (Collins 2009) and whose dynamic meanings can also be handled in terms of a subject's internal need (44) or the circumstances imposed need (42). Contrary to Collins (2009), we treat should in (57) as a dynamic, not a deontic modal. As there is no obvious supposed obligation/need deriving from some deontic source, the speaker questions the subject's internal need and the meaning can be captured by Is it necessary for her to have, or better yet Is she in need of.

(42) We should never take chances with our health. (Ishiguro 2016:68)

(43) Mi nikada ne bi trebalo da dovodimo u pitawe svoje zdravqe. (Išiguro 2003:88)

(44) I ought to go away for a bit. (Ishiguro 2016:271)

(45) Trebalo bi da nekud odem nakratko. (Išiguro 2003:579)

(46) Valjalo bi da negde odem nakratko.

(47) Why should she have a gallery of things done by us? (Ishiguro 2005:26)

(48) Зашто би она имала галерију са нашим стварима? (Ишигуро 2009:33)

The most frequent TE of must and have to is a full-fledged auxiliary morati whose dynamic meanings comprise both the internal necessity derived from the subject's characteristics and the one circumstantially imposed. Occasionally, trebati $^{16}$ in the conditional occurs as a TE of have to, which might be indicative of the intuitively felt semantic difference

\footnotetext{
${ }^{15}$ The negative of must is deontic expressing the obligation not to perform an action.

${ }^{16}$ For an exhaustive analysis of a range of various syntactic constructions trebati occurs in and their acceptance by the language norms, see Кликовац (2011).
} 
between must and have to. In the same form, it is a frequent TE of should/ought to. Trebati shows a high semantic and syntactic equivalency with need as both occur as full lexical verbs and modal auxiliaries. As morati is a strong modal, whereas trebati is a modal of medium modality (Novakov 2015), by using trebati, the view of a weaker need is expressed. Nonetheless, these modals appear to be nearly synonymous (35), which might indicate that they can alternate freely in the DynMod contexts. Syntactically and semantically, trebati is similar to valjati, a TE of should/ought to (see Alexander 2006:238), for both express medium strength modality and have kept their lexical meanings (Knežević \& Brdar 2011).

The conditional of the main verb, be and have most frequently, occurs as a TE of should, mainly in questions. Hence, a shift of the modal sub meaning can be detected: the TE stays in the DynMod domain but shifts from necessity to possibility.

\section{VOLITION}

As a subject oriented meaning, volition refers to the potentiality of an activity resulting from the subject's willingness/readiness. This umbrella notion covers three, or even four, senses, primarily related to will (Leech \& Svartvik 2002; Palmer 1979). Originating from the lexical verb meaning want or desire, will is a volitional modal also used for future reference. Hence, the dominant modal or non-modal meaning is not always clear. ${ }^{17}$ Yet, the combination of volition with present time (time distinct from that of the actualization) makes the modal component more separable (Huddleston \& Pullum 2002:193).

Volition is hardest to distinguish with $3^{\text {rd }}$ person subjects as our interpretation of the subject's volition can include a sort of inference, whereas it is most readily ascribable with $1^{\text {st }}$ person subjects. Yet, it is not easy to set the distinctions between the three strengths of volition. Namely, (49) can be interpreted in terms of weak volitional meaning, willingness glossed as be willing tolbe prepared to, or as an intermediate volition conveying the idea of intention, the latter being more plausible, though. Furthermore, as volition can be accounted for deontically, this utterance can be viewed as a commissive speech act. Likewise, interrogatives with $2^{\text {nd }}$ person subjects, question volition and indirectly convey a request to perform the action. As with can, this use of will can be seen in terms of dynamic or pragmatic implicatures. Negative contexts give rise to the clearest dynamic interpretation as non-volition is almost equivalent to refusal. This strong volitional meaning equals insistence or determination with a possible paraphrase want to or insist on (Leech 1987:78).

(49) I'll be out in a minute. (Ishiguro 2016:41)

(50) Izlazim za minut. (Išiguro 2003:94)

As agent oriented modalities are among the most frequent sources of the futures (Bybee et al. 1994), ${ }^{18}$ the semantic ambiguity between futurity and volition is found with other future reference forms: be about to (21), be going to, which generally conveys the weaker sense of intention rather than willingness (Collins 2009:147) clear in (51), and shall. Subject oriented meaning can be retrieved from the context, as in (53), where the subject had already stated the intention.

\footnotetext{
${ }^{17}$ Generally, there is a close intrinsic connection between futurity and modality (Huddleston \& Pullum 2002, Palmer 1986) and the issue of delimiting future meanings from modality exceeds the scope of this paper.

${ }^{18}$ One path of grammaticalization of the future is described as: desire $>$ volition $>$ intention $>$ prediction (Bybee et al. 1994: 256).
} 
(51) When are we going to go? (Ishiguro 2016:19)

(52) Kada krećemo? (Išiguro 2003:46)

(53) I shall do my best to bring back some order to these proceedings. (Ishiguro 2016:265)

(54) Učiniću sve što mogu da se priredba bar nekako nastavi. (Išiguro 2003:566)

Subject oriented will can refer to inanimate volition, or power, indicating how such objects will characteristically behave (Palmer 1979:110-111) or (general) properties of inanimates (Huddleston \& Pullum 2002:194) (55). ${ }^{19}$ With animate subjects, will can indicate propensity or tendency (57). Again, the existential sporadic meaning is sensed.

(55) Driving around the country now, I still see things that will remind me of Hailsham. (Ishiguro 2005:6)

(56) Сада док путујем земљом, још наилазим на ствари које ме подсете на Хејлшам. (Ишигуро 2009:10)

(57) Others will only joke about it, while others refuse to discuss it at all. (Ishiguro 2005:278)

(58) Други би се само шалили поводом тога, док неки потпуно одбијају да је спомињу. (Ишигуро 2009:280)

Modal hteti and its English counterpart will share analogous syntactic function. Although hteti unlike will, denotes futurity only in the eclectic forms, this testifies to the not yet finished grammaticalisation process of the futures in the two languages. Volitional hteti behaves syntactically like lexical verbs (Hansen 2007:36) and appears in so-called voluntative constructions. Apart from three shades of volition (Радовановић Војводић 2005:110), it occurs with existential meaning. Further, as shown by TEs, volition is expressed with lexical devices (nameravati, imati nameru, spremati se). The conditional in TEs often refers to habitual actions.

The frequent TEs with the indicative present allow for twofold explanation. First, some utterances are as a rule translated by corresponding cliché patterns in Serbian (Kalogjera 1970:70). Next, when the subject's intention/determination is viewed as of such a great extent that the action need be presented as already actualized and real, the present, which is used for intentions in one of its modal functions (Klikovac 2009), is an adequate TE.

\section{CONCLUSION}

Based on the provided conformed accounts of DynMod in English and Serbian, the general conclusion to be drawn is that the semantic category in question is a common basis shared by English and Serbian, but expressed with different formal systems in the two languages. The main findings are summarised in Table 1 below.

\footnotetext{
${ }^{19}$ Our corpus does not provide examples related to the satisfaction of the speaker's desires and needs typically illustrated with The car won't start.
} 
Table 1 Dynamic Modals in English and their Serbian TEs

\begin{tabular}{|c|c|c|c|c|c|c|}
\hline & English & & Serbian & & & \\
\hline \multirow{4}{*}{ 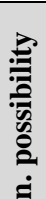 } & \multirow[t]{4}{*}{ Modal } & & Modal & Semi-modal & Modal lexeme & Tense and mood \\
\hline & & can & moći & umeti & znati $v$. & indic. present \\
\hline & & could & moći & umeti & $\begin{array}{l}\text { znati } v . \\
\text { biti u stanju / kadar adj. }\end{array}$ & indic. past \\
\hline & & may & moći & & & indic. present \\
\hline \multirow[t]{2}{*}{$\overline{\mathrm{a}}$} & Semi-modal & be able to & moći & & biti u stanju / kadar adj. & \\
\hline & & dare & & smeti & usuditi se v. & \\
\hline \multirow{5}{*}{ 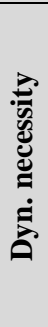 } & Modal & must & morati & & & \\
\hline & & should & trebati & & & $\begin{array}{l}\text { cond. present; } \\
\text { indic. present }\end{array}$ \\
\hline & Semi-modal & have to & $\begin{array}{l}\text { morati } \\
\text { trebati } \\
\text { valjati }\end{array}$ & & & \\
\hline & & ought to & trebati & & & indic. present \\
\hline & & need & trebati & & & $\begin{array}{l}\text { cond. present; } \\
\text { indic. present }\end{array}$ \\
\hline \multirow{4}{*}{ : } & Modal & will & & hteti & & $\begin{array}{l}\text { indic. present; } \\
\text { indic. future; } \\
\text { cond. present; }\end{array}$ \\
\hline & & shall & & hteti & & indic. future \\
\hline & Semi-modal & be about to & & & $\begin{array}{l}\text { želeti } v . \\
\text { spremati se } v .\end{array}$ & indic. future \\
\hline & & be going to & & & nameravati $v$ & $\begin{array}{l}\text { indic. future; } \\
\text { indic. present }\end{array}$ \\
\hline
\end{tabular}

The following are more precise conclusions regarding established similarities, contrasts and differences.

Absolute equivalency is present on the semantic level as both languages have devices at their disposal to express dynamic modal notions and concepts, whereas partial equivalency is found on the morpho-syntactic level. Next, the same grammatical classes, i.e. modals and semi-modals, are used to express DynMod in both languages and their dynamic meanings are generally most readily ascribable in the proper contexts: with animate subjects and activity verbs.

Partial correspondence is related to the possibility to render English modals various ways into Serbian including different morpho-syntactic and lexical elements. The findings suggest that the semantic values of English dynamic modals are often maintained in Serbian TEs. Dynamic must and morati are congruous elements of the two systems. Further, the high degree of correspondence is most evident between the pairs can/moći, will/hteti, need/trebati as these share the principal semantic-pragmatic meanings as well as syntactic properties. Yet, in some instances, Serbian modals are semantically coloured with the categories of tense and mood they combine with. As, unlike with English, there is no implication of actuality with Serbian modals, it is likely that in combination with the conditional mood the lower sense of actualization is sensed. As this is usually achieved in English by preterit, distal forms of the modals (e.g. can/could), this confirms the claim by Trbojević-Milošević (2004:179) that the conditional mood neutralises the lack of these forms in Serbian. 
Hence, the convergent, divergent and zero relations are noted. Convergent relations are present with must. The area of dynamic possibility demonstrates the most divergent area with can and could standing out, for their TEs comprise various grammatical and lexical forms. Zero relations are evident with TEs whose propositional content is presented as real or factual, containing the indicative tense, the present most frequently. Typically, this is the case with can occurring with catenative verbs and occasionally in its abilitative uses. Furthermore, as shown, the loss of modality meanings is possible with other dynamic modals. Besides the shift to non-modal meaning, a shift of the modality type/subtype may accompany the translation, admittedly rarely. As stated, a shift of DynMod subtype is noticed with medium strength dynamic necessity modals.

In this regard, a few possible explanations can be suggested. The first reason behind this may be associated with the nature of translation. Given that syntactic, semantic and pragmatic equivalence can be distinguished, the translator's decision as to whether to adopt semantic (the equivalence of what is said) or pragmatic equivalence (equivalence of what is implicitly communicated) is not always possible (Jaszczolt 2003). The preferences regarding the choice whether to follow semantic, pragmatic, syntactic or stylistic equivalence may change even within one text (Jaczscolt 2003). Thus, it appears that the detection of DynMod meanings depends on a native speaker's intuition that directs a chosen equivalence, which results in the omission of a modal component. Next, this inconsistency may be due to the faculative use of the necessity modals and can which have pseudomodal, indicative meaning (Јанић Стаменовић 2016:135). Further, this can be explained in part by the different tendencies of conveying modal meanings in the two languages. English has a highly developed set of modal verbs, the central exponents of modality, whereas Serbian rather tends to employ a variety of devices including the frequent uses of tenses in special modal functions.

Last not least, this discrepancy could be attributed to the specific nature of DynMod. Nonmodal TEs that the translators opted for can be accounted by the fact that dynamic modals in some uses convey little noticeable modal meaning to the sentence. That is, non-modal TEs are due to a low-degree modality of dynamic modals that Salkie (2009) pointed to. In a sense, this corroborates the view that dynamic meanings are somewhat peripheral to the semantic category of modality and proves that DynMod is the fuzziest of the three types. Nonetheless, the modality - non-modality continuum underlying the languages is pointed out.

\section{REFERENCES}

Alexander, R., (2006), Bosnian, Croatian, Serbian A Grammar with Sociolinguistic Commentary, Madison: University of Wisconsin Press.

Bybee, J, Perkins, R., Pagliuca., W., (1994), The evolution of grammar. Tense, aspect, and modality in the languages of the world. Chicago and London: University of Chicago Press.

Coates, J., Leech, G., (1980), "The Meanings of the Modals in British and American English", York Papers in Linguistics No. 8: pp. 23-34.

Collins, P., (2009), Modals and Quasi-modals in English, Amsterdam - New York: Rodopi.

Đorđević, R., (1994), Uvod u kontrastiranje jezika, Beograd: Filološki fakultet Univerziteta u Beogradu.

Gisborne, N., (2007), "Dynamic Modality", Skase Journal of Theoretical Linguistics Vol.4, No. 2: pp. 44-62. URL http://www.skase.sk/Volumes/JTL09/pdf_doc/4.pdf

Hansen, B., (2007), "A Morpho-syntactic Typology of Constructions with Modals in Serbian", In: Грковић-Мејџор, J., В., Ружић, С., Павловић (ур.) Лингвистичке свеске 6: Синтаксичка истражсивања (дијахроно-синхрони план), Нови Сад: Филозофски факултет, pp. 31-44.

Hoye, L., (1997), Adverbs and Modality in English, London \& New York: Longman. 
Huddleston, R., Pullum, G.K., (2002), The Cambridge Grammar of the English Language, Cambridge: Cambridge University Press.

Ishiguro, K., (2016) Unconsolded. Faber and Faber. (e-book) <http://www.bgcapp.com/books/download/ asin $=0679735879 \&$ type $=$ stream.$>10.11 .2016$.

Ishiguro, K., (2005), Never Let Me Go, New York: Alfred A. Knopf.

Išiguro, K., (2003), Bez utehe (prev. Nenad Tomović), Beograd: Plato.

Ишигуро, К., (2009), Не дај ми никада да одем (прев. Љиљана Марковић). Београд: Плато.

Јанић, А., Стаменковић, Д., (2016), "Модални глаголи must, should, can / morati, trebati, moći у енглеском и српском језику: опште карактеристике и изазови при превођењу", (The modal verbs must, should, can / morati, trebati, moći in English and Serbian: General characteristics and translation challenges), Зборник Матице српске за филологију и лингвистику LIX/2: str. 120-149.

Jaszczolt, K.M., (2003), "On Translating 'What Is Said': Tertium Comparationis in Contrastive Semantics and Pragmatics", Meaning Through Language Contrast Vol. 2: pp. 441-462.

Kalogjera D., (1970), "Ten English Modals and Their Equivalents in Srbo-Croatian", In: Filipović, R. (ed.) Reports 3. The Yugoslav Serbo-Croatian-English Contrastive Project, Zagreb: Institute of Linguistics, pp. 62-87.

Кликовац, Д., (2011), "Још једном о глаголу требати: теорија, употреба и норма", (Revisiting the verb trebati: theory, usage and norm), Наш језик XLII/3-4: стр. 3-24.

Кликовац, Д., (2009), "О презенту несвршених глагола за означавање будућих ситуација", Научни састанак слависта у Вукове дане 38 (1): стр. 57-71.

Knežević, B., Brdar, I., (2011), "Modals and Modality in Translation: a Case Study Based Approach", Jezikoslovlje 12/2: pp. 117-145. URL http://hrcak.srce.hr/index.php?show=clanak\&id_clanak_jezik=112724

Leech, G., (1987), Meaning and the English Verb, Second edition, London: Longman.

Leech, G., Svartvik, J., (2002), A Communicative Grammar of English, Third edition, London: Longman.

Novakov, P., (2007), "Modalnost i modalni glagoli u pojedinim gramatikama engleskog i srpskog jezika", U: Vučo, J. (ur.) Savremene tendencije u nastavi jezika i književnosti. Beograd: Filološki fakultet, str. 290-297.

Novakov, P., (2012), "Engleski modal can - promene i tendencije", (English Modal can - Changes and Tendencies), Godišnjak Filozofskog fakulteta u Novom Sadu XXXVII: str. 187-200.

Novakov, P., (2015), "Jezik, književnost, diskurs. Jezička istraživanja", U: Mišić Ilić, B., Lopičić, V. (ur.) Zbornik radova, Univerzitet u Nišu: Filozofski fakultet, str. 435-448.

Nuyts, J., (2006), "Modality: Overview and Linguistic Issues", In: Frawley, W. (ed.). The Expression of Modality, Berlin \& New York: Mouton de Gruyter, pp. 1-26.

Palmer, F.R., (1979), Modality and the English Modals, London: Longman.

Palmer, F.R. (1986/2001), Mood and Modality, Cambridge: Cambridge University Press.

Пипер, П., Клајн, И., (2013), Нормативна граматика српског језика. Нови Сад: Матица српска.

Пртљага, J., (2008), "Енглески модални глаголи can и will у епистемичкој и динамичкој употреби и њихови еквиваленти у српском језику", (English modals can and will in epistemic and dynamic use and their equivalents in Serbian language), Педагошка стварност LIV/7-8: стр. 730-746.

Quirk, R., Greenbaum, S., Geoffrey, L., Svartvik, J. (1985), A Comprehensive Grammar of the English Language, London and New York: Longman Group Limited.

Радовановић, А., (2012), "Динамички модали must и have (got) to у енглеском језику и њихови еквиваленти у српском језику", (Dynamic modals must and have (got) to in English and their equivalents in Serbian), Наслеђе, вол. 22, ФИЛУМ, Крагујевац, стр. 239-247.

Радовановић, М., Војводић, Д. (2005), "О једној језичкој универзалији", Славистика IX: стр. 103 -114.

Salkie, R., (2009), "Degrees of modality", In: Salkie, R., Busuttil, B., van der Auwera, J. (eds.) Modality in English: Theory and description ([TiEL] 58). Berlin: Mouton de Gruyter, pp. 79-103. URL http://www.brighton. ac.uk/languages/research/Salkie_Degrees_of_modality.pdf.

Trbojević-Milošević, I., (2004), Modalnost, sud, iskaz: epistemička modalnost u engleskom i srpskom jeziku, Beograd: Filološki fakultet. 


\section{DINAMIČKI MODALI U ENGLESKOM I SRPSKOM JEZIKU - KONTRASTIVNI PRISTUP}

Rad predstavlja pokušaj da se razmotri semantički domen dinamičke modalnosti u engleskom $i$ srpskom jeziku ispitivanjem dinamičkih modala u engleskom jeziku $i$ njihovih prevodnih ekvivalenata $u$ srpskom. U tom pogledu pokušaće da ponudi iscrpnu analizu podtipova dinamičke modalnosti $u$ ispitivanim jezicima. Međujezički posmatrano, modalnost se moža izražavati različitim gramatičkim kategorijama, ali je, međutim, primetna tendencija da tipološki srodni jezici ovu semantičku kategoriju izražavaju sličnim sredstvima. Očekuje se da će analiza pokazati da i engleski i srpski poseduju formalna sredstva za izražavanje dinamičkih modalnih značenja kao i da se ovaj tip modalnosti u navedenim jezicima izražava na sličan način. $U$ osnovi analize nalaze se dva komplementarna cilja: odrediti $i$ opisati sredstva kojima se ovaj tip modalnosti izražava u engleskom i srpskom i uporediti i kontrastirati ispitivane jezike. Jednosmerna kontrastivna analiza zasnovana na principu semantičke ekvivalencije sprovedena je na korpusu primera rečenica ekscerpiranih iz dva romana Kazua Išigura i njihovih prevoda kako bi se odredili kontrasti, razlike i sličnosti između ispitanih jezika. Nakon odeljaka posvećenim izražavanju dinamičke mogućnosti, dinamičke nužnosti/potrebe i volitivnosti, zaključak će ponudi sažeti prikaz centralnih rezultata sprovedene analize.

Ključne reči: dinamička modalnost, engleski, srpski, mogućnost, nužnost, volitivnost. 